\title{
FORUM
}

\section{TRANSMISSION OF HIV IN THE FIGHTING ARTS}

\author{
Caryl Verrier \\ Advocate of the High Court of South Africa \\ Stephen Tuson \\ Wits Law Clinic and School of Law, University of the Witwatersrand, Johannesburg
}

\section{THE FACTS}

Two fighters, $X$ and $Y$, engage in a bout. Unbeknown to fighter $Y$, but known to fighter $X$, fighter $X$ is HIV positive. Fighter $X$ fails to disclose his HIV-positive status to fighter $Y$ before the bout. During the course of the bout both fighters sustain open wounds, fighter $X$ bleeds into an open wound on fighter $Y$, and fighter $Y$ is infected with HIV.

\section{THE ENQUIRY}

The enquiry is:

Whether fighter $X$ would be guilty of any crime for infecting fighter $Y$ with HIV; and

Whether fighter $X$ would be liable to fighter $Y$ for damages in delict consequent upon his infecting fighter $Y$ with HIV.

\section{DISCLOSURE}

The right to privacy is enshrined in section 14 of the Constitution of the Republic of South Africa Act, 1996. However, neither the concept of 'privacy' nor the scope of the right to privacy is defined in the Constitution and it has therefore fallen to our courts, on a case by case basis, to attempt to define both the concept of 'privacy' and the scope of the right. (See, for example, Bernstein $v$ Bester NO 1996 (2) SA 751 (CC) in para [77].)

Following, particularly, the Constitutional Court decision of NM and Others $v$ Smith and Others (Freedom of Expression Institute as Amicus Curiae) 2007 (5) SA 250 (CC), the law is now clear that the right to privacy includes protection from disclosure of an individual's private and confidential medical information, including his or her HIV status. Put differently, there exists no general duty on an individual to disclose his or her HIV status, i.e. no one can be compelled to disclose his or her HIV status.
That said, where non-disclosure of one's HIV-positive status is coupled with conduct which results in, or causes, transmission of HIV to another, legal liability - be it criminal or civil or both - may follow; criminal liability flowing from the conduct through which HIV

\section{CRIMINAL LIABILITY}

is transmitted and civil liability flowing from the nondisclosure.

On the facts, two possibilities present themselves, namely attempted murder and assault with intent to do grievous bodily harm (assault GBH).

\section{ATTEMPTED MURDER}

On general principle, fighter $X$ would be guilty of attempted murder only where, inter alia:

(i) He directly intended to kill fighter $Y$ by infecting him with HIV, i.e. where he had intention in the form of dolus directus; or

(ii) He foresaw the possibility that he might kill fighter $Y$ (by infecting him with HIV) and persisted in his conduct, reckless as to whether or not that result ensued, i.e. where he had intention in the form of dolus eventualis.

(See C R Snyman, Criminal Law 4ed at 180-185; Law, Race \& Gender Unit, UCT, Sexual Offences and HIVIAIDS - Challenges Facing the Magistracy at 44-45.)

The Court would determine whether or not fighter $X$ had intention, in the form of either dolus directus or dolus eventualis, as a matter of inference from the proved facts. If the only reasonable inference from the proved facts were that fighter $X$ had the requisite intention, he would be convicted of attempted murder; if not, he would be acquitted. In order for the Court to draw the inference that he had intention in the form of dolus eventualis, it would merely have to be shown that the accused knew himself to be HIV positive, knew that HIV 
could be transmitted by bleeding into an open wound on another, and knew that HIV could cause death.

(See Snyman at 186-187; unreported decision of S V Nyalunga [2005] JOL 13254 (T).)

Whether fighter $X$ would be convicted of attempted murder would depend upon the facts. However, given the bare minimum of knowledge required of him to support a finding that he had intention in the form of dolus eventualis, it is our view that he would be likely to be convicted of attempted murder.

\section{ASSAULT WITH INTENT TO DO GRIEVOUS BODILY HARM}

Fighter $\mathrm{X}$ would be guilty of assault GBH only where, inter alia:

(iii) He directly intended to do grievous bodily harm to fighter $Y$ by infecting him with HIV, i.e. where he had intention in the form of dolus directus; or

(iv) He foresaw the possibility that he might do grievous bodily harm to fighter $Y$ by infecting him with HIV and persisted in his conduct, reckless as to whether or not that result ensued, i.e. where he had intention in the form of dolus eventualis.

(See Sexual Offences and HIV/AIDS - Challenges Facing the Magistracy at 46.)

It cannot be doubted that infection with HIV would qualify as 'grievous bodily harm'. (See $S \vee R 1998$ (1) SACR 166 (W) at 170.)

Further, given the competitive nature of a fight, fighter $X$ would necessarily satisfy at least one, if not both, of (iii) and/or (iv) and, in the result, would be guilty of assault $\mathrm{GBH}$.

The defence of consent (or volenti non fit injuria) may be raised by an accused to a charge of assault or assault $\mathrm{GBH}$ where the victim of the assault consented to the assault. Successfully raised, the defence has the effect of rendering lawful what would otherwise be an unlawful assault and is a complete defence to the charge. Indeed, the most common examples of cases in which the defence of consent is successfully raised are those in which the assault occurs during the course of a sporting event.

However, the defence of consent would not avail fighter $X$ for two reasons, those being:

- The defence operates only in respect of injuries that are normally expected in the particular sport under consideration and there is no possible room for arguing that infection with HIV is an injury which might normally be expected in a fighting arts bout; and
- The person consenting must have been aware of the true and material facts regarding the act to which he or she was consenting and there is, likewise, no possible room for arguing that, absent disclosure to fighter $Y$ of fighter $X$ 's HIV-positive status, fighter $Y$ was aware of the true and material facts regarding the act to which he was consenting.

(Snyman at 123-128.)

\section{DELICTUAL LIABILITY}

In the event, fighter $X$ would be convicted of assault $\mathrm{GBH}$.

No case has yet come before our courts in which the court has been required to determine whether the transmission of HIV consequent upon non-disclosure by the defendant of his HIV-positive status to the plaintiff attracts liability for damages in delict. In our view, however, should such a case come before our courts, the defendant will likely be found to be liable.

In order for fighter $Y$ to succeed in an action against fighter $X$ for damages, he would have to prove each of the elements of delictual liability, those being causation, negligence, wrongfulness and actual loss, on a balance of probabilities. (See Telematrix (Pty) Ltd t/a Matrix Vehicle Tracking v Advertising Standards Authority 2006 (1) SA 461 (SCA) in para [12] at 468A-C.)

\section{CAUSATION}

Proof of the element of causation would require proof that fighter X's non-disclosure caused fighter Y's loss. In practical terms, that would require proof of two facts, namely:

- That, had fighter $X$ disclosed his HIV-positive status to fighter $Y$, fighter $Y$ would not have been infected with HIV, i.e. steps could and would have been taken to prevent his being infected with HIV; and

- That fighter $X$ infected fighter $Y$ with HIV.

The first of those facts could be proved fairly easily by way of medical and other evidence. The second, however, presents some difficulty inasmuch as it is impossible to prove, medically, how or from whom someone contracted HIV. The court would therefore have to decide, as a matter of inference from the circumstantial evidence, whether, on the probabilities, fighter $X$ infected fighter $Y$. Relevant surrounding circumstances would include:

- Whether fighter $Y$ was HIV positive prior to coming into contact with fighter $X$; and

Whether fighter $Y$ was likely to have contracted HIV during the 'window period' after being exposed to HIV by fighter $X$.

Whether or not fighter $Y$ would be able to establish the

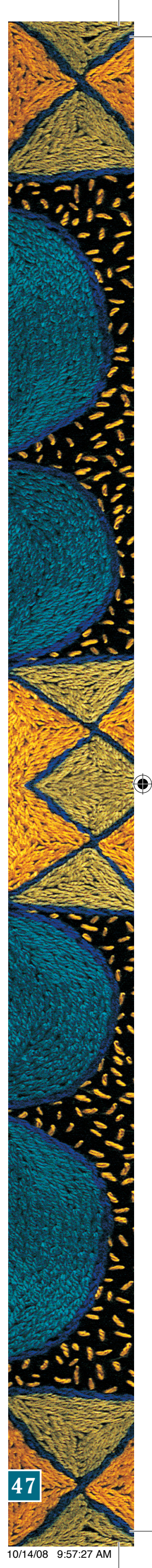


second fact would therefore depend on the evidence, and we are, for that reason, unable to express a definitive view as to whether fighter $Y$ would succeed in proving the element of causation.

\section{NEGLIGENCE}

Proof of negligence would require a finding by the court that the 'reasonable person' in the position of fighter $X$ :

Would have foreseen the possibility that his nondisclosure would cause transmission of HIV to fighter Y; and

Would have taken steps to guard against it.

(See Kruger $v$ Coetzee 1966 (2) SA 428 (A) at 430E; Minister of Education and Another v Wynkwart NO 2004 (3) SA 577 (C) at 582.)

Snyman at 214-215 explains the attributes of the diligens paterfamilias or 'reasonable person' as follows:

'By "reasonable person" is meant an ordinary, normal, average person. He or she is the person "of ordinary knowledge and intelligence". He or she is neither, on the one hand, an underdeveloped person, or somebody who recklessly takes chances. The reasonable person finds himself or herself somewhere between these two extremes. The reasonable person is therefore not somebody who runs away from every foreseen danger; he may sometimes take a reasonable risk. ...'

On this authority, it is our view that:

- The risk of transmission of HIV to another could never qualify as a 'reasonable risk'.

- The reasonable person against whom the standard of fighter X's conduct would be judged would be the 'reasonable person' who has been diagnosed as being HIV positive and who is possessed of an average HIV patient's knowledge of HIV and its transmission.

- An average HIV patient, and therefore the reasonable person in fighter $X$ 's position, would have been aware:

- that there existed a risk of transmission of HIV from him to fighter $Y$ in the event of his bleeding into an open wound on fighter $Y$

- that the prompt administration of antiretroviral therapy to fighter $Y_{\text {, post-exposure, would }}$ significantly reduce the risk of transmission of HIV

- that HIV is progressively debilitating and, ultimately, fatal

a that there is no known cure for HIV and/or AIDS; and

- that patients infected with HIV face stigma, shunning and sometimes danger to life and limb.
- In order to prevent (or reduce the risk of) transmission of HIV to fighter $Y$, the reasonable person in fighter X's position would have disclosed his HIV-positive status:

- to fighter $Y$, so as equip him to make an informed decision as to whether or not he wished to continue with the bout and thereby assume the risk of being infected with HIV; and/or

- to the medical personnel at the ringside, so as to alert him or her promptly to administer antiretrovirals to fighter $Y$ in the event of fighter $X$ 's bleeding into an open wound on fighter $Y$.

- Fighter X's conduct, i.e. his non-disclosure, would therefore have fallen short of the standard of conduct required of him.

- In the result, the court would find that the element of negligence had been proved.

\section{WRONGFULNESS}

Proof of the element of wrongfulness would require a finding by the Court that, as a matter of law, fighter X's non-disclosure was wrongful.

The question whether a particular act or omission is wrongful is a conclusion of law which the court will draw upon a consideration of the circumstances of the case, the legal convictions of the community, considerations of policy and constitutional norms, values and principles. (See Van Eeden v Minister ofSafety and Security (Women's Legal Centre Trust, as Amicus Curiae) 2003 (1) SA 389 (SCA) in paras [9]-[10] and [12]; Gouda Boerdery BK V Transnet 2005 (5) SA 490 (SCA) in para [12] at 498G499B; Minister van Polisie v Ewels 1975 (3) SA 590 (A); S $M$ Goldstein \& Co (Pty) Ltd v Cathkin Park Hotel (Pty) Ltd and Another 2000 (4) SA 1019 (SCA); Local Transitional Council of Delmas and Another $v$ Boshoff 2005 (5) SA 514 (SCA).)

Fighter X's non-disclosure would therefore be found to be wrongful if, taking into account constitutional norms, values and principles, the Court considered that the 'legal convictions of the community and considerations of policy' determined his non-disclosure to be wrongful.

It is our view that, indeed, taking into account:

- the competing constitutional rights to privacy, dignity and equality of fighter $X_{1}$ on the one hand, and the rights to life, bodily integrity and freedom of association of fighter $Y$, on the other hand

- the fact that the promptadministration of antiretroviral therapy, post exposure to HIV, significantly reduces the risk of transmission

- the stigma, shunning and sometime danger to life and limb faced by patients infected with HIV 


\section{BARC \\ ensuring clinical trials \\ always measure up \\ to expectations}

- From Routine to Esoteric Testing

- Global Equivalent Results

- Result Reporting Within 24 Hours

- Quality Assurance

- Electronic Data Transfer

- Controlled Long Term Storage

BARC Johannesburg

Telephone: +27 11 358-0901

BARC Durban

Telephone: +27 31 308-6512
BARC Pretoria

Telephone: +27 12-483-0255

BARC Cape Town

Telephone: +27214484311

\section{$B|A| R \mid C$}

BIOANALYTICAL RESEARCH CORPORATION

SOUTH AFRICA PTY (LTD)

W W W.B A R C S A. C O.Z A

$W W W . B A R C L A B . C O M$ 
the progressively debilitating effects of HIV

- the fact that there is no known cure for HIV and thus the inevitable progression of HIV towards AIDS and, ultimately, death

- the emotional, financial and social consequences for the families of patients infected with HIV; and

a the fact that HIVIAIDS has reached pandemic proportions in South Africa and is having crippling effects on the country's social structure and economy,

there can be no doubt that a Court would find that 'the legal convictions of the community and considerations of policy' determined fighter X's non-disclosure to be wrongful.

\section{ACTUAL LOSS/HARM}

The element of loss - being, inter alia, fighter Y's medical expenses, loss of earning capacity and general damages - could fairly easily be proved by way of a combination of medical, actuarial and other evidence.

\section{DEFENCE OF CONSENT OR VOLENTI NON FIT INJURIA}

As in the criminal setting, a defendant in an action for damages for assault can raise the defence of consent or volenti non fit injuria where the plaintiff consented to the assault and, if successfully raised, this will be a complete defence to the plaintiff's claim. In Boshoff $v$ Boshoff 1987 (2) SA 694 (0), it was held that the defence of volenti non fit injuria is, specifically, available in an action for damages arising out of injuries sustained in the course of a lawful sport or physical recreation.

Again, however, as in the criminal setting, fighter $X$ would not succeed in his defence of consent as the defence does not extend to negligence on his part. In other words, while fighter $Y$ clearly consented to assume the risk of being assaulted by fighter $X$, it cannot conceivably be said that he consented to assume the risk of the negligent transmission to him of HIV by fighter $X$. As expressed in Vorster $v$ Santam Insurance Co Ltd and Another 1973 (2) SA 186 (W) at 191, fighter X's defence of consent would fail as, absent disclosure, fighter $Y$ would not have known the 'nature and extent of the risk' he was assuming or 'appreciate[d] the risk to life and limb for himself' and the cause of his injury would have arisen from an element not covered by the volens.

\section{CONCLUSION}

In conclusion, it is our view - assuming that the evidence establishes causation - that fighter $Y$ would succeed in proving each of the elements of delictual liability and would therefore succeed in his action for damages.

\section{CLUB RULES}

The option that immediately presents itself to a fighting arts club or association, as a means of protecting its HIV-positive fighters from the potential legal liability discussed above and of protecting its HIV-negative fighters from becoming infected with HIV, is for the club or association to invoke its constitutional right to freedom of association (as enshrined in section 18 of the Constitution) and to adopt a rule to the effect that each of its members is required to submit to a test for HIV and is further required to disclose the results of the test to the appropriate member or members of the association. (See Taylor v Kurtstag NO and Others 2005 (1) SA 362 (W) in paras [37] and [48] and Bernstein v Bester (supra) in para [77].)

It is not suggested that a member identified as being HIV positive should necessarily be excluded from fighting, but merely that knowledge of a fighter's HIV status is essential in order to place an HIV-positive fighter's opponent in a position to give his informed consent to participating in a bout with the HIV-positive fighter and in order to alert the ringside medical personnel promptly to administer antiretroviral therapy in the event of a situation arising in which his opponent is exposed to HIV.

It is our view that, although a rule of a fighting arts club or association requiring disclosure by members of their HIV status would necessarily constitute a limitation on the rights of its HIV-positive members to privacy, equality, dignity and freedom of association:

- Whether or not the limitation is justifiable would have to 'considered within the context' of section 36(1) of the Constitution, i.e. it would have to be considered whether the limitation was 'reasonable and justifiable in an open and democratic society based on human dignity, equality and freedom, taking into account all relevant factors, including' the factors set out in sections $36(1)(a)$ to $(e)$

- The rule would have as its object the protection of the right of the fighting arts club or association to freedom of association, as well as the rights of its HIV-negative members to life, bodily integrity and dignity (sections 31, 11, 12 and 10 of the Constitution, respectively).

- The right to privacy is inviolable only in the 'the inner sanctum of a person' or 'the truly personal realm' and becomes subject to limitation as the individual leaves behind the inner sanctum and enters into relationships outside of his or her 'closest intimate sphere'.

- Relationships between fighters would qualify as falling outside of the individual's 'inner sanctum' or 'closest intimate sphere' so that, in context, the individual 


\section{PCR-based HIV viral-load testing $\mathrm{r}$ $=$ the waly form \\ Human Immunodeficiency Virus (HIV) is the etiologic agent of the Acquired Immunodeficiency \\ Several viral load strategies can be employed - measurement of HIV p24 antigen in serum, quantitative} Syndrome (AIDS). Subsequent to its initial brief and non-specific clinical presentation, HIV infection is associated with a clinically stable, asymptomatic phase that can last for several years. During the asymptomatic phase of infection, viral replication and clearance appear to be highly dynamic processes. Production of viral particles and infection of $\mathrm{CD}^{+} \mathrm{T}$ lymphocytes are offset by equally high rates of virus clearance. Continuous cell destruction and subsequent replacement ultimately results in comparatively stable levels of both plasma viremia and $C D 4^{+}$ cells. During this period however, a steady depletion of $\mathrm{CD}^{+}{ }^{+} \mathrm{T}$ lymphocytes leads to severe immunodeficiency, multiple opportunistic infections, malignancies and eventually, death.

With the advent of highly active antiretroviral treatment (HAART), it became critically important to accurately detect and measure HIV levels in peripheral blood in order to institute and monitor therapy. culture of HIV from plasma, or by direct measurement of viral RNA in plasma using nucleic acid amplification or signal amplification technologies. Culture and antigen detection methods are not only cumbersome and time consuming to perform, but may be vastly insensitive in asymptomatic patients. These methods are not suitable for routine use and are best suited for use in dedicated research facilities. Signal amplification assays have been largely successful for HIV viral load determination and are well suited for use in developing countries.

A major drawback of these methods is the relatively long incubation time needed to complete an assay, thus not being conducive to high-paced diagnostic environments. Although signal amplification methods have proved themselves as being robust and cost-effective, this technology is now largely being surpassed by polymerase chain reaction (PCR)based nucleic acid amplification assays.
Several real-time PCR-based assays are currently available for commercial use and all methods are essentially based on three principles; i) isolation of HIV-1 RNA from a blood sample, ii) reverse transcription and formation of complementary DNA and iii) PCRbased amplification and detection of the required target sequence. Commercial real-time PCR detection platforms are designed for near-total automation, minimizing the risk for operatorintroduced error. In addition to automated sample preparation, these assays contain carefully designed probes targeting different areas situated on the HIV-1 genome, making them highly sensitive and specific. Internal amplification controls minimize the risk of PCRinhibition and simultaneously permit accurate quantitation of HIV-1 RNA in the sample. In addition to improved accuracy, rapid turnaround times are made possible through the use of automation and real-time PCR detection methods.

AMPATH Laboratories currently have access to all major commercial brands of HIV viral load platforms available in Southern Africa. This is a unique scenario; ideally situated to handle complex or difficult-to-diagnose clinical cases encompassing several different detection methods. HIV viral load assays are conducted by highly trained medical scientists in co-operation with dedicated pathologists. Continuous support and collaboration with our suppliers lead to active research and development in the field of molecular analysis, providing diagnostic services of the highest standard to our valued clients.

For more information, please contact Ampath at 012-427 1800 or go to www.ampath.co.za

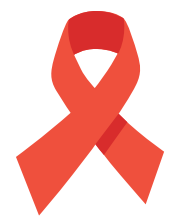

$$
\begin{aligned}
& \text { P A T O L O E · P A T H O L O } \underset{P R 0520005200431}{S} \text { T S } \\
& \text { Drs Du Buisson, Bruinette, Kramer Inc./Ing. }
\end{aligned}
$$

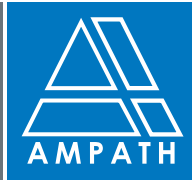


fighter's right to privacy would become subject to limitation.

- On a delicate balancing of the conflicting rights of HIV-positive members and the rights of the fighting arts club or association, and 'considered within the context of section 36(1) of the Constitution', the individual fighter's rights would be required to give way to the rights of the club or association and the rule would be 'reasonable and justifiable in an open and democratic society based on human dignity, equality and freedom' and thus valid and enforceable.

Although, perhaps, any fighting arts club or association might baulk at the idea of adopting a rule that circumscribes any of its member's constitutional rights, it is our view that, in the light of the gravity of the consequences of the negligent transmission of HIV (those being, the potential legal liability discussed above for the HIV-positive fighter, and, ultimately, death for his opponent), the adoption of such a rule would be not only legally but also morally defensible and, indeed, would appear to be the only option presently available to a club or association to protect its fighters against the risk of infection.

AUTHORITIES

C R Snyman, Criminal Law 4th ed. at 123-128, 180-185, 186-187 \& 214-215. Law, Race \& Gender Unit, UCT, Aspects of HIVIAIDS and the Law at 22-23 \& 119

Law, Race \&t Gender Unit, UCT, Sexual Offences and HIV/AIDS - Challenges Facing the Magistracy, at 44-45 \&t 46

Bernstein v Bester NO 1996 (2) SA 751 (CC) in paras [67], [75] \& [77].

Boshoff v Boshoff 1987 (2) SA 694 (0)

Gouda Boerdery BK v Transnet 2005 (5) SA 490 (SCA) in para [12]

Local Transitional Council of Delmas and Another v Boshoff 2005 (5) SA 514 (SCA)

Minister of Education and Another v Wynkwart NO 2004 (3) SA 577 (C) at 580C-D, 5821 \& $583 \mathrm{H}$

Minister van Polisie v Ewels 1975 (3) SA 590 (A).

Minister of Safety and Security v Mohofe 2007 (4) SA 215 (SCA) in para [12]

Nel v Venter 1997 (4) SA 1014 (D).

NM and Others v Smith and Others (Freedom of Expression Institute as Amicus Curiae) 2007 (5) SA 250 (CC) in paras [34], [40] \& [41]-[43].

$R v$ Horn 1958 (3) SA 457 (A) at 463, 464 \& 465.

Sv Ngubane 1985 (3) SA 677 (A) at 685F-G S v Nyalunga [2005] JOL 13254 (T).

SVR 1998 (1) SACR 166 (W) at 170.

SvRapitsi 1987 (4) SA 351 (A).

S M Goldstein \& Co (Pty) Ltd v Cathkin Park Hotel (Pty) Ltd and Another 2000 (4) SA 1019 (SCA) in para [7].

Telematrix (Pty) Ltd t/a Matrix Vehicle Tracking v Advertising Standards Authority 2006 (1) SA 461 (SCA) in para [12] at 468A-C.

Taylor v Kurtstag NO and Others 2005 (1) SA 362 (W) in paras [37], [48] \& [58].

Van Eeden v Minister of Safety and Security (Women's Legal Centre Trust, as Amicus Curiae) 2003 (1) SA 389 (SCA) in paras [9]-[10] \& [12]

Vorster v Santam Insurance Co Ltd and Another 1973 (2) SA 186 (W) at 191 \&t 192.

\section{TOLL-FREE NATIONAL HIV HEALTH CARE WORKER HOTLINE}

The Medicines Information Centre, situated within the University of Cape Town's Faculty of Health Sciences, provides a Toll-Free National HIV Hotline to all health care workers in South Africa

Call us for any HIV/ARV-related clinical enquiries, including:

- HIV testing • Post-exposure prophylaxis • Management of HIV in pregnancy and PMTCT

- Antiretroviral therapy • Drug interactions

- Treatment and prophylaxis of opportunistic infections • Drug availability

- Adherence support • Adverse events

\section{6}

Weekdays $08 h 30$ - $16 h 30$

Staffed by specially trained and highly skilled drug information pharmacists
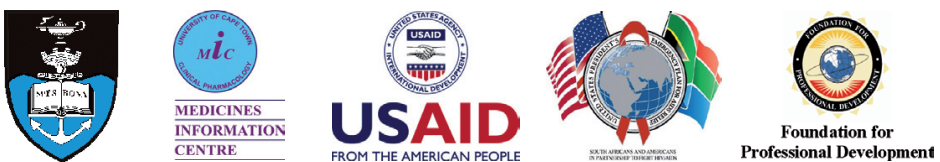